\title{
The role of humanities in the course of transmitting social memory
}

\author{
Marina S. Kalney ${ }^{1^{*}}$ \\ ${ }^{1}$ National Research University of Electronic Technology (MIET), Department of Philosophy, \\ Sociology and Political Science, Moscow, Russia
}

\begin{abstract}
The article examines the contradiction between the transformation of information technology into an integral part of contemporary educational activities and the threat of reducing the quality of the educational process and dehumanizing the individual, resulting from the implementation of digital educational technologies. The need for distance work and remote communication is particularly evident in the situation of the pandemic, which requires, on the one hand, restricting direct interpersonal contacts to prevent the spread of infection, and on the other hand - continuing labor activity to prevent an economic downturn. The disadvantages of the distance framework in the educational process concern a decrease in discipline among students, a deterioration in the quality of learning of educational material, economic inaccessibility for low-income families, insufficient coverage of territories with cellular communication, as well as housing conditions that do not allow organizing remote work and training. These shortcomings become a threat to increasing social stratification due to the impossibility of general access to even basic education. The essence of the protests against distance learning shows that the problems are seen not only in the lack of organization of the learning process but also in the very fact of abandoning the traditional learning model. One of the factors of such a threat is the absolutization of the role of information technology in the learning process, which leads to a deterioration in the level of education. To resolve this contradiction, the authors propose to consider the role of humanitarian knowledge as a meaningful aspect of the educational process.
\end{abstract}

Keywords: digital technologies, educational process, humanitarian knowledge.

\section{Introduction}

The existing socio-cultural situation has given a special urgency to the problem of the digitalization of education. The implementation of information technology changes the traditional order of the educational process organization, as well as its content. It is well known that these issues cause a sharp divergence of opinions that goes beyond the scientific and pedagogical community. On the one hand, the digitalization of education is considered as an innovative process, a radical change in the education process according to the transition

\footnotetext{
*Corresponding author: marina.kalnej@yandex.ru
} 
trends to information and computer civilization. On the other hand, the digitalization of education is seen as a process of dehumanization of the individual, its transformation into an object of global manipulation. In this regard, it is necessary to consider the contradictions of using information technology in education.

\section{Methods}

The article examined the approaches to education in a post-industrial society based on the standpoints of A. Toffler, A.A. Zinoviev, and S.B. Pereslegin, who considered various aspects of the education nature in post-industrial society. The works of $\mathrm{N}$. Wiener and S. Lem provided an opportunity to consider digital technologies, their capabilities, and limitations in the educational process. Special attention was paid to the humanities knowledge as a meaningful aspect of education. The role of humanitarian knowledge in the process of transmitting social memory and moral values was shown in the writings of J. Frazer, J.J. Rousseau, F. Fukuyama, I. Wallerstein, A.A. Zinoviev, E. Fromm, and several contemporary researchers. All this allowed considering the relationship between digital technologies and humanitarian knowledge as a form and content of the educational process.

\section{Discussion}

The American sociologist A. Toffler was one of the first who raised the issues concerning changing education according to the trends of the transition to an information and computer society. The sociologist considered the disappearance of the traditional education model as one of the main trends in the development of the information and computer society: "Although lectures are still needed to perform a small range of tasks, this form of classes will inevitably recede into the background with the introduction of new teaching methods, ranging from role-playing games to computer conferences and immersion of students in, so to speak, imaginary adventures" [1: 442-443].

Similarly, the Russian researcher S.B. Pereslegin considers the main trend in the education system development to be the transition to alternative educational structures of corporate education, recurrent education, role-playing, and organizational-activity games, education in communities (including criminal ones), as well as family education. In these structures, new educational mechanisms of recurrent education, adult education, hetero-age education, and the knowledge approach will be implemented [2: 452].

In other words, the education system that has existed for the last centuries is declared obsolete and needs to be replaced with new approaches, in which the main emphasis is on the ability to work with applied tasks and quickly find and process the desired information, rather than on general theoretical training, hierarchy, and system-based approach.

However, the negative aspects of this trend are that such education does not provide sufficient skills to analyze information and critically evaluate it. An example of identifying such a trend is the work of the Russian philosopher A.A. Zinoviev "The Global Human AntHill": "Not only the process of education is robotized but also its very content. We are taught not so much to understand something but to operate with intellectual technical devices. To understand the content of sciences at the level of their creators, a relatively small number of exceptional individuals are now sufficient for the entire planet. But they are somehow selected, fall into the elite of humanity, and somewhere do their job to maintain the intellectual and creative potential of our Global Humant Ant-Hill. The functions of understanding in the old (pre-computer) sense are taken away from ninety-nine point ninetynine of people and transferred to "thinking" machines" [3: 10]. 
In other words, shifting away from the traditional education model, rejecting a systematic presentation of theoretical material as well as student-teacher interaction in the knowledge transfer process, reduce the ability to critically analyze and understand the transmitted knowledge. The lack of this ability increases the ability to manipulate the individual. This is exactly one of the main contradictions of the existing trends in the development of education. On the one hand, information technology has become an integral part of human activities while, on the other hand, the absolutization of its role in education is seen as a threat.

It is necessary, however, to pay attention to the ontological aspect of this problem. In this regard, the analysis of the problems of artificial intelligence presented in the works of S. Lem deserves attention. Concerning artificial intelligence, the Polish futurologist states the following: "We are talking about the fact that the "electronic brain", the computer "mind" (or whatever else to call it) of the robot would have in mind, psychically perceive, anticipate the GOALS to which it will move, while we will not know in advance about its individual decisions that create a semantic unity" [4: 317].

In other words, information technology is an effective means of communication, information storage, and processing, but it cannot perform the functions of an active subjective reflection of objective reality. To a large extent, the absolutization of the role of information and computer technologies is associated with the absolutization of physical and mathematical knowledge. For example, N. Wiener associates the origin of this absolutization with the success of mathematical physics at the beginning of the 20th century: "The development of the natural sciences was accompanied by the widespread use of mathematical apparatus, which became fashionable in the social sciences" [5: 91]. In other words, the success of mathematical physics has led to the fact that the mathematization of knowledge has become the ideal of all knowledge, including social knowledge. At that, information technology as the most effective means of applying the mathematical apparatus has become considered the most effective means of transmitting all knowledge. The one-sidedness of this approach is obvious.

In this regard, it should be noted that one of the obvious trends in the existing education system is a shift in emphasis towards forming individual skills and abilities (called competencies) to the detriment of holistic world perception and worldview. This latter quality is developed due to humanitarian knowledge, which requires a more detailed analysis of its specifics.

It is well known that the essence of human nature consists in the displacement of natural instincts by extrabiological programs of behavior. In contrast to the genetic memory and natural instincts of the animal, the human perception of the world is inextricably linked with the transmission of social memory and norms of social behavior from previous generations. Humanitarian knowledge, in all its historical manifestations, served initially the mechanism of transmission of these regulators of human activity from mythology and religion to contemporary political ideologies and the humanities. All these forms of social consciousness are characterized by the description of the objective laws of the surrounding social reality, the transmission of memory about the events of the past, the promise of remuneration for behavior that corresponds to the established norms of social life.

In particular, J. Frazer pointed out that "if the one acts from the love or fear of God, he is religious; if the other acts from the love or fear of man, he is moral or immoral according as his behavior comports or conflicts with the general good" [6: 71]. In other words, belief in the supernatural in the form of a myth or religion is designed to control human behavior. At the same time, myth and religion also serve the function of describing the supernatural powers that guide and control natural phenomena and human life [7: 69-70]. The very essence of such a description implies the transfer of information about the actions of these powers in the past - in other words, to social memory. 
With the rejection of belief in the supernatural, the idea of civil religion was originated in the modern age, which, according to J.J. Rousseau "would make one love his responsibilities" to the positive dogmas, to which the French thinker attributed the following: "the existence of the powerful, intelligent, beneficent, prescient, and provident Divinity, the life to come, the happiness of the just, the punishment of the wicked, the sanctity of the social contract and the laws" [7: 33]. Here, there is a regulation of behavior through the transmission of a value system and social memory of the past experience of the powers that regulate human behavior.

The social sciences and humanities have finally moved from the idea of divine intervention into natural and social processes to the description of objective laws of natural and social existence. However, understanding the historical process, according to which "History was not a blind concatenation of events, but a meaningful whole, in which human ideas concerning the nature of a just political and social order developed and played themselves out", is noteworthy [8: 96-97]. Therefore, historical knowledge not only transmits social memory but also contains the basic values that control the behavior of the individual. Along with history, these same functions are evident in other humanities.

At that, attention is drawn to the fact that humanitarian knowledge does not always meet the criteria of objectivity as an ideal of science. For example, I. Wallerstein points out that "social science disciplines considered themselves nomothetic, in search of universal laws, consciously modeling themselves on the good example of physics (as nearly as they could)" [9: 277]. Zinoviev points out the contradictions of this approach: "Social science must recognize that science is not impartial and cannot be such, because scientists are members of society, and they are not free from it either physically or intellectually" [10: 210]. Similarly, E. Fromm notes that "The consciousness of the members of the elites is a product of their social existence. They consider their way of organization and the values that are implied in it as being in "the best interests of man", they have a picture of human nature which makes this assumption plausible, they are hostile to any idea or system which questions or endangers their own system" [11: 277].

In other words, humanitarian knowledge is not objective knowledge. In traditional society, myth and religion have created an illusory picture of the world to subordinate the individual to society; at that, the authority of this worldview was supported by repressive measures on the part of the social medium and the state. Political ideology as a "civil religion" in the modern era has also created in the individual a system of illusory ideas about the world, often supported by the repressive political machinery of the state. Humanitarian knowledge is distinguished here by the fact that it appeals to the authority of objective, scientifically grounded, and, consequently, unquestionable knowledge. According to this, it would be possible to conclude that humanitarian knowledge is illusory and that it is necessary to abandon it in favor of mastering the skills that are in demand in the labor market.

However, the extensive experience of foreign studies shows not only the transformation of information technology into an integral part of the educational process but also the need to preserve the traditional components of the educational process [12-17]. Therefore, "the contemporary view toward education determines the existence of several interrelated subjects in the educational space, knowing each other, accepting communication and dialogue in it. Such educational interaction results in unique individually developed techniques, methods, tools, and technologies of self-improvement, self-actualization of subjects included in the education system". [18: 8]. This means that information technology should not be considered as an end in itself and the only criterion for evaluating the effectiveness of the educational process but as a means of transmitting the content of the educational process. An integral part of this process is humanitarian knowledge, which is understood not so much as an objective reflection of the laws of social reality but as the transmission of social memory, moral and value orientations, and behavioral programs between generations. 


\section{Conclusion}

The analysis of the education digitalization processes allows drawing the following conclusions. On the one hand, the transition of the education system to the use of information technology is considered an integral part of the development of post-industrial society. On the other hand, the rejection of traditional education in favor of digital education is seen as a threat to the decline in the education quality, dehumanization of the personality, and its transformation into an object of manipulation. This contradiction is largely due to the absolutization of the role of information technology. The achievements of physics and mathematics at the beginning of the recent century gave rise not only to the absolutization of physical and mathematical knowledge as an ideal of science but also to the absolutization of computer technology as a means of processing physical and mathematical knowledge. At that, the limited ability of computer technology to provide a subjective reflection of objective reality was not taken into account. Therefore, without denying the role of information technology as a means of transmitting and storing information, it is necessary to focus on the humanities as a meaningful element of the educational process. This element provides not so much an objective reflection of the patterns of the surrounding world (this is the task of natural science knowledge) but rather the transmission of social memory and basic moral values between generations.

\section{References}

1. A. Toffler, Shok budushchego [Future shock] (AST, Moscow, 2002)

2. S.B. Pereslegin, Novyye karty budushchego ili Anti-Rend [New maps of the future or Anti-Rand] (AST, Terra Fantastica, Moscow, Saint Petersburg, 2009)

3. A.A. Zinoviev, Globalnyi cheloveynik [The Global Human Anthill] (Tsentropoligraf, Moscow, 1997)

4. S. Lem, Moloh [Moloch] (AST, Hranitel, Moscow, 2006)

5. N. Wiener, Tvorets i robot [Creator and robot] (Progress, Moscow, 1966)

6. J.G. Frazer, Zolotaya vetv: Issledovaniye magii i religii [The golden bough: a study in magic and religion] (Eksmo, Moscow, 2006)

7. J.-J. Rousseau, Ob obshchestvennom dogovore. Traktaty [The Social Contract and Other Later Political Writings] (Kanon-Press, Kuchkovo pole, Moscow, 1998)

8. F. Fukuyama, Konets istorii i posledniy chelovek [The end of history and the last man] (AST, Ermak, Moscow, 2005)

9. I. Wallerstein, The end of the world as we know it: Social science for the twenty-first century (University of Minnesota Press, Minneapolis, 1999)

10. A.A. Zinoviev, Faktor ponimaniya [Understanding factor] (Algoritm, Eksmo, Moscow, 2006)

11. E. Fromm, Chelovek dlya samogo sebia. Issledovaniye psihologicheskih problem etiki [Man for himself, an inquiry into the psychology of ethics] (AST, Moscow, 2010)

12. Y.M. Al-Dheleai, Z. Tasir, N.F. Jumaat, SAGE Open, 10(1), 1-8 (2020). https://doi.org/10.1177\%2F2158244019899094

13. T.Z. Aldahdough, P. Nokelainen, V. Koronen, SAGE Open, 10(1), 1-20 (2020). https://doi.org/10.1177\%2F2158244019899441

14. A. Lepp, J.E. Barkley, A.C. Karpinski, SAGE Open, 9(1), 1-9 (2019). https://doi.org/10.1177\%2F2158244018824505 
15. I.V. Moura, L.B. de Almedia, W.V. da Silva, SAGE Open, 10(4), 1-17 (2020). https://doi.org/10.1177\%2F2158244020967942

16. Xiaogin Li, SAGE Open, 10(4), 1-9 (2020). https://doi.org/10.1177\%2F2158244020963614

17. E. V. Yakovleva, A. V. Denisenko, E. F. Shaleeva, S. I. Artemyeva, N. P. Rodinova, V. M. Ostrovkov, M. S. Kalney, Cuestiones Politicas, 37(64), 196-209 (2020)

18. S.E. Shishov, V.A. Kalney, E.G. Rahimova, Socio-Humanitarian Research And Technology, 1, 3-12 (2020). https://doi.org/10.12737/2587-912X-2020-3-11 